\title{
Family members' satisfaction with the care flow in the Pediatric Emergency Department
}

\author{
A satisfação dos familiares sobre o fluxo de atendimento no Pronto-Socorro Pediátrico \\ La satisfacción de los familiares sobre el flujo de atención en el Departamento de Emergencia Pediátrico
}

Giselle Pinto de Oliveira Sá Macedo'
ORCID: 0000-0002-1993-129X
Maria D'Innocenzo'
ORCID: 0000-0002-1869-9468

'Universidade Federal de São Paulo, Escola Paulista de Enfermagem. São Paulo-SP, Brasil.

How to cite this article:

Macedo GPOS, D'Innocenzo M. Family members' satisfaction with the care flow in the Pediatric Emergency Department.

Rev Bras Enferm [Internet]. 2019;72(2):435-41.

doi: http://dx.doi.org/10.1590/0034-7167-2018-0388

Corresponding Author:

Giselle Pinto de Oliveira Sá Macedo

E-mail: gigimacedo@yahoo.com.br

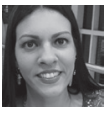

Submission: 08-06-2018

Approval: 09-09-2018

\section{ABSTRACT}

Objective: To evaluate the satisfaction index of the pediatric patient's caregiver (person responsible for the child) regarding the waiting time for the care flow in an emergency service. Method: A prospective, cross-sectional, quantitative study with 300 family members in the Pediatric Emergency Department of a general hospital. An instrument was used to analyze the service flow, waiting time and satisfaction evaluation. Descriptive statistical analysis was performed. Results: The satisfaction index of caregivers was statistically significant $(p<0.05)$ the lower was the waiting time for patient screening, care by the doctors and for receiving the prescribed medication. Caregivers who took their children to the emergency department because of the disease ( $p-0.029)$ or because they did not find doctors in other hospitals ( $p-0.021$ ) were satisfied with the waiting time for this service. Conclusion: The quality of care is evaluated as satisfactory by caregivers when children are treated quickly in the Pediatric Emergency Department.

Descriptors: Qualitty of Health Care; Quality Assurance, Health Care; Patient Satisfaction; Emergency Nurse; Child.

\section{RESUMO}

Objetivo: Avaliar oíndice de satisfação do responsável pelo paciente pediátrico referente aos tempos de espera do fluxo de atendimento em um serviço de emergência. Método: Estudo transversal, prospectivo, quantitativo, realizado com 300 familiares no ProntoSocorro Pediátrico de um hospital geral. Um instrumento foi utilizado para análise do fluxo do serviço, tempo de espera e avaliação da satisfação. Realizada análise estatística descritiva. Resultados: $O$ índice de satisfação dos responsáveis foi estatisticamente significante $(p<0,05)$ quanto menor o tempo de espera para classificação dos pacientes na triagem, atendimento pelos médicos e recebimento da medicação prescrita. Os acompanhantes que levaram suas crianças ao Pronto-Socorro devido à patologia $(p-0,029)$ ou por não encontrarem médicos em outros hospitais $(p-0,021)$, ficaram satisfeitos com o tempo de espera para o atendimento neste serviço. Conclusão: A qualidade de atendimento manifestada pelos acompanhantes é satisfatória quando as crianças são atendidas com rapidez no Pronto-Socorro Pediátrico.

Descritores: Qualidade da Assistência à Saúde; Garantia da Qualidade dos Cuidados de Saúde; Satisfação do Paciente; Enfermagem em Emergência; Criança.

\section{RESUMEN}

Objetivo: Evaluar el índice de satisfacción del cuidador del paciente pediátrico con relación a los tiempos de espera del flujo de atención en un servicio de emergencia. Método: Estudio transversal, prospectivo, cuantitativo, realizado con 300 familiares en el Departamento de Emergencia Pediátrico de un hospital general. Se utilizó un instrumento para analizar el flujo del servicio, el tiempo de espera y la evaluación de la satisfacción. Se realizó un análisis estadístico descriptivo. Resultados: El índice de satisfacción de los cuidadores fue estadísticamente significativo $(p<0,05)$ cuanto menor el tiempo de espera para la clasificación de los pacientes en el triaje, atención por los médicos y recepción de la medicación prescrita. Los acompañantes que llevaron a sus niños al Departamento de Emergencia debido a la patología $(p-0,029)$ o por no encontrar médicos en otros hospitales $(p-0,021)$, quedaron satisfechos con el tiempo de espera para la atención en este servicio. Conclusión: La calidad de atención es percibida como satisfactoria por los acompañantes cuando los niños son atendidos con rapidez en el Departamento de Emergencia Pediátrico.

Descriptores: Calidad de la Atención de Salud; Garantía de la Calidad de Atención de Salud; Satisfacción del Paciente; Enfermería de Urgencia; Niño 


\section{INTRODUCTION}

The emergency department is a part of the hospital environment with uninterrupted operation that can attend patients with serious health conditions, acute problems, and imminent risk of death who need accurate and immediate care. It provides high complexity services and observation beds to ensure quality care that meets the demands ${ }^{(1)}$.

Users with less serious and non-urgent clinical conditions contribute to overcrowding in emergency services and increase the waiting time, generate work overload for the health team, and cause their own discomfort and physical and emotional exhaustion $^{(2-3)}$.

In emergency services for severely ill children of the Brazilian National Health System (Portuguese acronym: SUS) is also provided care for pediatric patients with simpler diseases and outpatient treatment. This clientele contributes to higher waiting time in the Pediatric Emergency Department, and interferes in the care of children with acute and severe conditions ${ }^{(4)}$.

In pediatrics, the definition of urgency is a controversial topic. Several reasons lead the patient's caregiver (person responsible for the child) to seek the emergency department and they depend on many factors, such as: parents' inexperience, previous loss of children, clarification of doubts, easier access, immediate examination, among others ${ }^{(5)}$.

At the beginning, with the greater demand of users in emergency services, was provided care without clinical evaluation, which was done on a first-come first-served basis. In 2004, with the increase in the number of patients, the Ministry of Health created the booklet of the National Humanization Policy (Portuguese acronym: $\mathrm{PNH}$ ), which established the risk classification (screening) of patients seeking emergency services ${ }^{(6)}$.

Risk classification is a dynamic process in which adult or pediatric patients are evaluated and classified according to their vital parameters and potential risk. Care is prioritized by changes in patients' clinical conditions that lead to life-threat, instead of the first-come first-served care, as it used to be in the past ${ }^{(3,7)}$.

The Manchester protocol is one of the most widely used in screening, and can be applied to all age groups in emergency services because it is evidence based, guarantees reliability of patients' clinical condition, and is stratified into five colors or categories. The risk classification by the color system consists of: Red (emergent: immediate care by the medical team), Orange (very urgent: 10 minutes), Yellow (urgent: 60 minutes), Green (less urgent: 120 minutes) and Blue (not urgent: 240 minutes) $)^{(1,8)}$.

Studies have shown the constant concern with improving the treatment of acute and chronic diseases with preventive care in order to reduce the unnecessary demand of pediatric patients in emergency services ${ }^{(9)}$.

In this context, the presence of a qualified multiprofessional team is fundamental in pediatric emergency services, especially nurses with practical skills and specific knowledge. These professionals should be able to recognize severity situations, minimize complications to children's clinical picture, and thus provide quality differentiated care to pediatric patients and their family in emergency services ${ }^{(10)}$.

\section{OBJECTIVE}

To evaluate the satisfaction index of pediatric patients' caregivers regarding the waiting times for the care flow in a pediatric emergency service.

Thus, the study hypothesized that caregivers of pediatric patients would demonstrate satisfaction with the quality of care when their children were treated quickly by the multiprofessional team when seeking the emergency service.

\section{METHOD}

\section{Ethical aspects}

The research was approved by the Research Ethics Committee of the Universidade Federal de São Paulo, and were respected the norms of Resolution number $466 / 12$ of the National Health Council. All participants signed the Informed Consent form after being advised about the study objectives. The author of the validated instrument ${ }^{(11)}$ provided formal authorization for its use during the study.

\section{Design, location and period of the study}

A prospective, cross-sectional, descriptive, quantitative study. It was developed in the Pediatric Emergency Department of a general public hospital focused on teaching and research and located in the city of São Paulo. The data collection period were 60 days during the months of February and March of 2016.

\section{Study sample; inclusion and exclusion criteria}

In this study was used a convenience sample. From the moment the researcher was notified about the medical conduct (hospitalization with patients' transfer to specific sectors of the institution or discharge), the pediatric patient's caregiver was approached, clarified about the importance of the study and invited to participate. The population consisted of pediatric patients admitted to the emergency department (newborns to adolescents aged up to 14 years, 11 months and 29 days of life). The caregiver was the main informant during the data collection period. Although the caregivers who expressed their level of satisfaction were responsible for the children (patients were minors), the validated questionnaire presented the same applicability of the previous study, when used in this pediatric setting. A statistician was consulted, and a pre-test was conducted in order to adjust the instrument for the care flow in the Pediatric Emergency Department, estimate the time required for completing it properly, and establish the number of participants per day of data collection.

The nursing directorate of the institution provided the total number of visits to the Pediatric Emergency Department during all months of 2015. Thus, through statistical consultancy, was calculated the sample of the study and were stipulated the months of data collection that could suffer influence of seasonality.

The sample was calculated using the total number of children attending the emergency department in February and March, based on numeric data of patients who visited the pediatric 
emergency service in the year prior to the study. Since the literature had no articles offering an estimate for the sample calculation, the statistician considered as a confidence level that the researcher interviewed five caregivers daily during the 60 days of study with the purpose of evaluating the quality of care provided to pediatric patients when visiting the emergency department.

In the sample, were included 300 pediatric patients. The caregivers who did not agree to participate after being clarified about the reasons for the study were excluded.

\section{Study protocol}

During the data collection, was used a script created to evaluate the flow of pediatric patients admitted to the emergency department, and to characterize the sample regarding the following criteria: name initials, age, sex, risk classification at screening, diagnostic hypothesis, destination after admission to the Pediatric Emergency Department, and length of stay in the emergency service in number of hours.

Some variables were categorized into 0 and 1 for the easier understanding. In the statistical analysis of these variables, category 0 refers to 'no' and category 1 represents 'yes'.

An instrument validated in a previous research and composed of 18 questions related to the care flow was used for the evaluation of children's caregivers regarding their satisfaction with the quality of care and the time spent between arrival of pediatric patients to the emergency department until their leave either by discharge or internal transfer to specific sectors of the institution. At the end of the instrument, there was an open question about the reason for the child's caregiver seeking the emergency department.

In the instrument validated, category 0 refers to the opinion 'dissatisfaction', in which were grouped the following items: totally dissatisfied/very dissatisfied/little dissatisfied/little satisfied. Category 1 refers to'satisfaction', in which were grouped very satisfied/completely satisfied. This dichotomous grouping occurred in the same way as in the instrument validated in the aforementioned study. Gross satisfaction questions (values from 1 to 6) were categorized as 0 (gross values from 1 to 4 ) and 1 (gross values from 5 to 6 ), and correlated to the satisfaction index that ranged from 0 to $100 \%$.

\section{Analysis of results and statistics}

The Spearman correlation and the Mann-Whitney test were used for statistical analysis and a significance level of $5 \%(p<0.05)$ was adopted. The results were organized in a database in Excell ${ }^{\circ}$ and analyzed through the Statistical Package for Social Science (SPSS), version 19. The descriptive analysis characterized the subjects of the study and the times recorded in hours, which were presented in absolute and relative frequencies in the tables.

\section{RESULTS}

Table 1 records the children's profile during the care flow when visiting the Pediatric Emergency Department in the months of February and March of 2016.
Table 1 - Sociodemographic characteristics and care flow of pediatric patients who visited the Pediatric Emergency Department, São Paulo, Brazil, 2016 ( $N=300)$

\begin{tabular}{|c|c|c|}
\hline Characteristics & $\mathbf{N}$ & $\%$ \\
\hline Age $^{*}$ & 4.6 & 4.2 \\
\hline \multicolumn{3}{|l|}{ Sex } \\
\hline Female & 159 & 53.0 \\
\hline Male & 141 & 47.0 \\
\hline \multicolumn{3}{|l|}{ Risk classification } \\
\hline Green & 214 & 71.4 \\
\hline Yellow & 64 & 21.3 \\
\hline Blue & 15 & 5.0 \\
\hline Red & 7 & 2.3 \\
\hline \multicolumn{3}{|l|}{ Pathologies } \\
\hline Respiratory diseases & 139 & 46.3 \\
\hline Digestive diseases & 67 & 22.3 \\
\hline Dermatological diseases & 25 & 8.3 \\
\hline Infectious diseases & 22 & 7.4 \\
\hline Neurological diseases & 22 & 7.4 \\
\hline Otorhinolaryngological diseases & 8 & 2.6 \\
\hline Renal diseases & 6 & 2.0 \\
\hline Metabolic diseases & 3 & 1.0 \\
\hline Orthopedic diseases & 2 & 0.7 \\
\hline Exogenous intoxication & 2 & 0.7 \\
\hline Heart diseases & 2 & 0.7 \\
\hline Hematologic diseases & 1 & 0.3 \\
\hline Endocrinological diseases & 1 & 0.3 \\
\hline \multicolumn{3}{|l|}{ Destination } \\
\hline Discharge & 221 & 73.7 \\
\hline Ambulatory & 72 & 24.0 \\
\hline Evasion & 1 & 0.3 \\
\hline Refusal of procedure & 2 & 0.7 \\
\hline Intensive Care Unit & 4 & 1.3 \\
\hline
\end{tabular}

Table 2 - Satisfaction index of pediatric patients' caregivers in relation to the waiting Paulo, Brazil, 2016

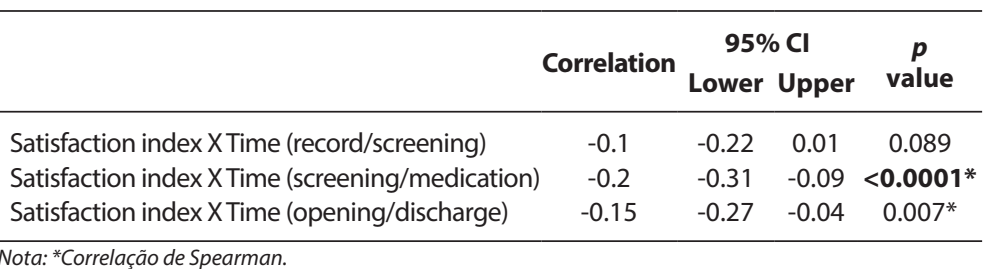

Table 2 shows the correlation between the satisfaction index and the quantitative variable (time). There were statistically significant differences ( $p<0.0001$ and $p$-0.007) for the time between screening and medication (screening/medication), and the time between opening the attendance record and discharge from the emergency service (opening/discharge), respectively.

Regarding the times, both are inversely correlated with the satisfaction index. In other words, the shorter the time spent by patients in screening, medical consultation and receiving the prescribed medication (screening/medication), the greater the caregivers' satisfaction. The same correlation is valid for the time that patients spent in opening the attendance record in the service in order to have access to the full consultation and be discharged and/or transferred from the Pediatric Emergency Department (opening/discharge). The shorter the time spent in this process, the higher the satisfaction expressed by children's caregivers.

Among the pathologies presented by pediatric patients, Table 3 shows the statistically significant difference between patients 
Table 3 - Caregivers' satisfaction index associated with waiting times and diseases presented by pediatric patients who visited the Pediatric Emergency Department of a public hospital, São Paulo, Brazil, $2016(\mathrm{~N}=300)$

\begin{tabular}{|c|c|c|c|c|c|}
\hline Time & Variables & Category & Average & $\mathbf{n}$ & $\begin{array}{c}p \\
\text { value }\end{array}$ \\
\hline \multirow{2}{*}{ Time (record/screening) } & \multirow{2}{*}{ Respiratory diseases } & 0 & 0.5 & 161 & \multirow{2}{*}{0.227} \\
\hline & & 1 & 0.58 & 139 & \\
\hline \multirow[t]{2}{*}{ Time (screening/medication) } & \multirow[t]{2}{*}{ Respiratory diseases } & 0 & 1.16 & 161 & \multirow{2}{*}{0.422} \\
\hline & & 1 & 0.98 & 139 & \\
\hline \multirow{2}{*}{ Time (opening/discharge) } & \multirow{2}{*}{ Respiratory diseases } & 0 & 7.6 & 161 & \multirow{2}{*}{0.563} \\
\hline & & 1 & 6.11 & 139 & \\
\hline \multirow{2}{*}{ Time (record/screening) } & \multirow{2}{*}{ Digestive diseases } & 0 & 0.54 & 233 & \multirow{2}{*}{0.59} \\
\hline & & 1 & 0.53 & 67 & \\
\hline \multirow[t]{2}{*}{ Time (screening/medication) } & \multirow[t]{2}{*}{ Digestive diseases } & 0 & 1.02 & 233 & \multirow[t]{2}{*}{0.23} \\
\hline & & 1 & 1.27 & 67 & \\
\hline \multirow[t]{2}{*}{ Time (opening/discharge) } & \multirow[t]{2}{*}{ Digestive diseases } & 0 & 7 & 233 & \multirow{2}{*}{0.486} \\
\hline & & 1 & 6.6 & 67 & \\
\hline \multirow{2}{*}{ Time (record/screening) } & \multirow{2}{*}{ Infectious diseases } & 0 & 0.54 & 278 & \multirow{2}{*}{0.361} \\
\hline & & 1 & 0.55 & 22 & \\
\hline \multirow[t]{2}{*}{ Time (screening/medication) } & \multirow[t]{2}{*}{ Infectious diseases } & 0 & 1.07 & 278 & \multirow{2}{*}{0.358} \\
\hline & & 1 & 1.21 & 22 & \\
\hline \multirow[t]{2}{*}{ Time (opening/discharge) } & \multirow[t]{2}{*}{ Infectious diseases } & 0 & 6.85 & 278 & \multirow[t]{2}{*}{0.514} \\
\hline & & 1 & 7.71 & 22 & \\
\hline \multirow[t]{2}{*}{ Time (record/screening) } & \multirow[t]{2}{*}{ Neurological diseases } & 0 & 0.56 & 278 & \multirow[t]{2}{*}{$<0.0001 *$} \\
\hline & & 1 & 0.26 & 22 & \\
\hline \multirow[t]{2}{*}{ Time (screening/medication) } & Neurological diseases & 0 & 1.1 & 278 & 0.063 \\
\hline & & 1 & 0.81 & 22 & \\
\hline Time (opening/discharge) & Neurological diseases & 0 & 6.31 & 278 & $<0.0001 *$ \\
\hline & & 1 & 14.46 & 22 & \\
\hline Time (record/screening) & Dermatological diseases & 0 & 0.53 & 275 & 0.124 \\
\hline & & 1 & 0.58 & 25 & \\
\hline Time (screening/medication) & Dermatological diseases & 0 & 1.11 & 275 & 0.09 \\
\hline & & 1 & 0.73 & 25 & \\
\hline Time (opening/discharge) & Dermatological diseases & 0 & 7.21 & 275 & $0.002 *$ \\
\hline & & & 3.64 & 25 & \\
\hline
\end{tabular}

Table 4 - Satisfaction index of caregiver associated with waiting times and reasons for seeking the Pediatric Emergency Department of a public hospital, São Paulo, Brazil, 2016 (N=300)

\begin{tabular}{cccccc}
\hline Time & Reasons & Category & Average & $\mathbf{n}$ & $\begin{array}{c}\boldsymbol{p} \\
\text { value }\end{array}$ \\
& & & & & \\
& & 0 & 0.55 & 237 & \\
Time (record/screening) & Proximity to residence & 1 & 0.49 & 63 & 0.329 \\
Time (screening/medication) & Proximity to residence & 0 & 1.07 & 237 & 0.796 \\
& & 1 & 1.1 & 63 & \\
Time (opening/discharge) & Proximity to residence & 0 & 6.53 & 237 & 0.611 \\
& & 1 & 8.32 & 63 & \\
Time (record/screening ) & Disease & 0 & 0.53 & 119 & 0.261 \\
& & 1 & 0.54 & 181 & \\
Time (screening/medication) & Disease & 0 & 1.07 & 119 & 0.865 \\
& & 1 & 1.08 & 181 & \\
Time (opening/discharge ) & Disease & 0 & 8.71 & 119 & $0.029^{*}$ \\
& & 1 & 5.72 & 181 & \\
Time (record/screening) & Reference hospital & 0 & 0.56 & 247 & $0.043^{*}$ \\
& & 1 & 0.44 & 53 & \\
Time (screening/medication) & Reference hospital & 0 & 1.14 & 247 & 0.069 \\
& & 1 & 0.8 & 53 & \\
Time (opening/discharge) & Reference hospital & 0 & 6.65 & 247 & 0.886 \\
& & 1 & 8.11 & 53 & \\
Time (record/screening) & Other closed hospitals & 0 & 0.54 & 296 & 0.756 \\
& & 1 & 0.72 & 4 & \\
Time (screening/medication) & Other closed hospitals & 0 & 1.07 & 296 & 0.246 \\
& & 1 & 1.29 & 4 & \\
\hline & & & & To be continued
\end{tabular}

diagnosed with neurological diseases $(p<0.0001)$ and dermatological diseases ( $p-0.002)$. Therefore, patients with neurological diseases had a more agile service in relation to the time between opening the attendance record and screening (record/ screening), which generated satisfaction among caregivers.

Patients diagnosed with neurological and dermatological diseases spent a shorter time in the service when compared to the others, because the time between opening the attendance record and discharge from the Pediatric Emergency Department (opening/discharge) between diseases of the neurological system $(p<0.0001)$ and the dermatological system $(p-0.002)$ showed a statistically significant difference.

Table 4 shows a statistically significant difference in the association of at least one of the times used for some reasons, namely: disease ( $p-0.029)$, reference hospital ( $p$ 0.043 ) and lack of doctors in another service ( $p-0.021)$, and these factors contributed to the caregivers' search for the Pediatric Emergency Department. Relatives who took their children to the emergency department for considering they were ill or who did not find doctors in other hospitals, spent less time to be served, that is, from opening the attendance record until discharge and/or transfer from the Pediatric Emergency Department (opening/discharge). This finding reveals a statistically significant satisfaction index $(p<0.05)$ when compared to family members who sought the service for other reasons.

The average length of time spent by patients in the Pediatric Emergency Department, since admission with the opening of the attendance record until leaving the sector, was seven hours and 31 minutes.

\section{DISCUSSION}

In studies conducted in pediatric emergency services, the age range was similar to that of the present sample. Users' mean age was of 4.6 years, i.e., the pre-school age group that includes children aged between 2 and 6 years. However, the predominance of male patients ${ }^{(12)}$ in the other study differed from the $53.0 \%$ of female patients participating in the present study. Such gender-associated divergence can be justified by the profile of institutions where the studies were developed. 
Table 4 (concluded)

\begin{tabular}{|c|c|c|c|c|c|}
\hline Time & Reasons & Category & Average & $\mathbf{n}$ & $\begin{array}{c}p \\
\text { value }\end{array}$ \\
\hline Time (opening/discharge) & Other closed hospitals & $\begin{array}{l}0 \\
1\end{array}$ & $\begin{array}{c}6.78 \\
16.67\end{array}$ & $\begin{array}{c}296 \\
4\end{array}$ & 0.112 \\
\hline Time (record/screening) & Lack of doctors in another service & $\begin{array}{l}0 \\
1\end{array}$ & $\begin{array}{l}0.52 \\
0.73\end{array}$ & $\begin{array}{c}280 \\
20\end{array}$ & 0.525 \\
\hline Time (screening/medication) & Lack of doctors in another service & $\begin{array}{l}0 \\
1\end{array}$ & $\begin{array}{l}1.06 \\
1.26\end{array}$ & $\begin{array}{c}280 \\
20\end{array}$ & 0.261 \\
\hline Time (opening/discharge) & Lack of doctors in another service & $\begin{array}{l}0 \\
1\end{array}$ & $\begin{array}{l}6.74 \\
9.35\end{array}$ & $\begin{array}{c}280 \\
20\end{array}$ & $0.021^{*}$ \\
\hline Time (record/screening) & No health insurance & $\begin{array}{l}0 \\
1\end{array}$ & $\begin{array}{l}0.54 \\
0.81\end{array}$ & $\begin{array}{c}298 \\
2\end{array}$ & 0.214 \\
\hline Time (screening/medication) & No health insurance & $\begin{array}{l}0 \\
1\end{array}$ & $\begin{array}{l}1.08 \\
0.38\end{array}$ & $\begin{array}{c}298 \\
2\end{array}$ & 0.293 \\
\hline Time (opening/discharge) & No health insurance & 0 & $\begin{array}{l}6.94 \\
2.27\end{array}$ & $\begin{array}{c}298 \\
2\end{array}$ & 0.192 \\
\hline
\end{tabular}

Notes: *Mann-Whitney test; $0=$ No; $1=$ Yes.

In this study, the green classification/less urgent (71.4\%) and yellow classification/urgent (21.3\%) prevailed. In the southern region of the country, researchers showed that patients using the Pediatric Emergency Department were classified as green $(34.0 \%)$ and yellow $(43.6 \%)^{(1)}$. On the other hand, in the Netherlands, the orange classification (very urgent) was attributed to $34.0 \%$ of pediatric patients who visited the emergency service ${ }^{(13)}$.

The difference in results between the studies conducted in Brazil and the Netherlands may be associated with the level of training of nursing professionals who performed the screening, and may overestimate or underestimate the risk classification attributed to patients. The overestimated risk classification offers better safety for the classified patient, but contributes to increase the number of clinically stable patients admitted to the emergency service, instead of being directed to ambulatory sectors. On the other hand, the underestimated classification as less urgent or non-urgent can cause serious damages to the health of patients who should be served as a priority ${ }^{(1)}$.

In this study, diseases of the respiratory system (46.3\%) and digestive system (22.3\%) prevailed among children in the sample. A similar study reported that respiratory diseases (56.2\%), and gastrointestinal diseases (16.6\%), followed by viral infections (13.1\%) were the main pathologies that affected the pediatric public and led them to pediatric emergency services ${ }^{(14)}$.

In $73.7 \%$ of the sample of the present study, was found a similar result to that of a national study ${ }^{(1)}$, in which most children admitted to the emergency department were discharged after medical care or after receiving drug treatment directed to their acute clinical condition.

Chinese researchers reported a high satisfaction rate for caregivers of children treated in a shorter and faster time in a pediatric emergency service. Long waiting times at screening or the emergency department resulted in family members' dissatisfaction and behavioral reactions, such as stress and anxiety, when their children were not seen promptly or in a short period of time ${ }^{(5)}$.

A study conducted in a Pediatric Emergency Department in Spain registered greater satisfaction of caregivers when their children faced less waiting time to receive medical care, that is, time spent between screening, medical care and probable conduct through medication prescription (screening/medication). This corroborates the findings of the present study $(p<0.0001)^{(12)}$.

Among the neurological pathologies, head trauma caused by falls and convulsive crisis are the most common diseases in children that lead families to seek the Pediatric Emergency Department. In emergency services, neurological related diseases must have priority care and be classified in the most complex color system by a team of qualified nurses in order to avoid possible complications if care is not performed quickly ${ }^{(15-16)}$.

This finding demonstrates that the satisfaction rate $(p<0.0001)$ of children's caregivers was associated with the effectiveness and agility of care according to the severity of the pediatric patient referred to the emergency department, which decreases the time interval between opening the attendance record and screening (record/screening). The complexity of a neurological disease after stabilization of the acute condition can lead to children's transferring, reduce their permanence in the emergency service and, thus, reduce the time in the emergency department (opening/discharge).

Skin-related pathologies are classified as emergencies. Urticarias can trigger serious clinical pictures in pediatric patients, such as intense pruritus, generalized papules, facial edemas, respiratory discomfort, anaphylaxis and severe hypotension ${ }^{(17)}$.

According to researchers, caregivers sought the Pediatric Emergency Department more frequently when their children presented pathologies affecting the skin or integument system ${ }^{(18)}$.

Thus, the caregivers of most children diagnosed with skin conditions considered their clinical picture as an emergency, which caused the visit to the emergency department because of less waiting time.

The present study registered a significant satisfaction index regarding the waiting time among caregivers who sought the Pediatric Emergency Department for the following reasons: disease ( $p-0.029)$, considering the hospital a reference service ( $p-0.043)$ and lack of doctors in another service (p-0.021).

This result is corroborated by a Spanish study in which were found high levels of satisfaction, free from irritation of the parents, when their children with more serious illnesses were attended in the emergency service with greater attention and speed ${ }^{(12)}$.

In a systematic review of literature performed between 1980 and 2012 in the United States, it was found that parents' low knowledge on health favors visits to the emergency department, because they consider the Pediatric Emergency Department as a reference to the treatment of their children. This fact contributes to the greater waiting time and overcrowding of the service ${ }^{(19)}$.

Different results were found in other studies, where the main compromising causes of quality of care in adult and pediatric emergency services were the following: lack of professionals in emergency services, absence of resources linked to the lack of structure for patient/family embracement, long waiting time and overcrowding ${ }^{(20-21)}$.

Researchers reported caregivers'satisfaction with the quality of the service provided when their children waited a short time for the 
process of screening by the nursing team, receiving medical care and, consequently, spent a short time in the emergency service ${ }^{(2)}$.

\section{Limitations of the study}

The limitations of this study are related to the use of a validated instrument in an adult emergency department, and when directed to the caregivers of children who visited an emergency service, it can restrict their perceptions in the pediatric environment.

\section{Contributions to the area of nursing, health or public policy}

The research findings will contribute to increase the quality of care provided to children and their families in the Pediatric Emergency Department. In addition, the results can support further studies on the care flow in emergency services linked to the population awareness policy and thus, optimize the waiting time for care.

\section{CONCLUSION}

The conclusion was that the quality of care expressed by companions is satisfactory when pediatric patients are served quickly and effectively in the emergency service. The waiting time spent in care was shorter for family members who visited the emergency department because of diseases manifested by children, which resulted in a significant satisfaction index among the interviewed caregivers.

Thus, the need for cultural change of patients and families who seek care in the emergency department in order to increase the quality of care for the population in emergency services.

\section{ACKNOWLEDGEMENTS}

Thanks to the institution where the study was conducted, and to all participants.

\section{REFERENCES}

1. Amthauer C, Cunha MI. Manchester Triage System: main flowcharts discriminators and outcomes of a pediatric emergency care. Rev LatinoAm Enfermagem [Internet]. 2016[cited 2018 May 13];12:e2779-85. Available from: http://www.scielo.br/pdf/rlae/v12/7.pdf

2. Fitzpatrick N, Breen DT, Taylor J, Paul E, Grosvenor R, Heggie K, et al. Parental satisfaction with paediatric care, triage and waiting times. Emerg Med Australas [Internet]. 2014[cited 2018 May 13];26(2):176-82. Available from: https://www.ncbi.nlm.nih.gov/pubmed/24708008

3. Oliveira TA, Pinto KA. Welcome with risk classification and the conditions of access in emergency service: user's evaluation. Ciênc Cuid Saúde [Internet]. 2015[cited 2018 May 13];14(2):1122-9. Available from: http://periodicos.uem.br/ojs/index.php/CiencCuidSaude/article/ view/22897/14791

4. Arrué AM, Neves ET, Buboltz FL, Jantsch LB, Zanon BP. Demand of a pediatric first-aid service: characterization of the nursing care. Rev Enferm UFPE [Internet]. 2013[cited 2018 May 13];7(4):1090-7. Available from: https://periodicos.ufpe.br/revistas/revistaenfermagem/article/ viewFile/11584/13606

5. Lin GX, Yang YL, Kudirka D, Church D, Young CK, Reilly F, et al. Implementation of a Pediatric Emergency Triage System in Xiamen, China. Chin Med J (Engl) [Internet]. 2016[cited 2018 May 13];129(20):2416-21. Available from: https://www.ncbi.nlm.nih.gov/pmc/articles/ PMC5072252/

6. Ministério da Saúde (BR). Humaniza SUS - acolhimento com avaliação e classificação de risco: uma paradigma ético-estético no fazer em saúde [Internet]. Brasília: Ministério da Saúde; 2004 [cited 2018 May 13]. 48p. Available from: http://bvsms.saude.gov.br/bvs/publicacoes/ acolhimento_classificaao_risco_servico_urgencia.pdf

7. Pascual-Fernández MC, Ignacio Cerro MC, Jíménez-Carrascosa MA. Triage evaluation making in a pediatric emergency department of a tertiary hospital. Rev Enferm [Internet]. 2014[cited 2018 May 13];37(3):30-5. Available from: https://www.ncbi.nlm.nih.gov/ pubmed/24851340

8. Storm-Versloot MN, Vermeulen H, van Lammeren N, Luitse JS, Goslings JC. Influence of the Manchester triage system on waiting time, treatment time, length of stay and patient satisfaction: a before and after study. Emerg Med J [Internet]. 2014 [cited 2018 May 13];31(1):138. Available from: http://www.ncbi.nlm.nih.gov/pubmed/23302504

9. Seiger N, van Veen M, Almeida H, Steyerberg EW, van Meurs AH, Carneiro R, et al. Improving the Manchester Triage System for pediatric emergency care: an international multicenter study [Internet]. 2014 [cited 2018 May 13]; 9(1):e83267. Available from: https://doi. org/10.1371/journal.pone.0083267

10. Wheeler DS, Geis G, Mack EH, Le Master T, Patterson MD. High-reliability emergency response teams in the hospital: improving quality and safety using in situ simulation training. BMJ Qual Saf [Internet]. 2013[cited 2018 May 13];22(6):507-14. Available from: https://www.ncbi.nlm. nih.gov/pubmed/23457361

11. Castellanos PL. Comparação entre a satisfação do usuário com os serviços oferecidos num hospital geral e a percepção gerencial dessa satisfação [Dissertação]. São Paulo (SP): Escola de Administração de Empresas de São Paulo, Fundação Getúlio Vargas; 2002.

12. Fernández-Castillo A, Vilches-Lara MJ.Factors related to dissatisfaction and anger in parents of children treated at paediatric emergency services. An Pediatr (Barc) [Internet]. 2015[cited 2018 May 13];82(1):12-8. Available from: http://http://www.analesdepediatria.org/ es-linkresolver-factores-desencadenantes-insatisfaccion-e-ira-S1695403314001787

13. van lerland Y, Seiger N, Van Veen M, Moll HA, Oostenbrink R. Alarming signs in the Manchester triage system: a tool to identify febrile 
children at risk of hospitalization. J Pediatr[Internet]. 2013[cited 2018 May 13];162(4):862-6. Available from: https://www.ncbi.nlm.nih.gov/ pubmed/23149176

14. Lima LMB, Almeida NMGS. Mothers searching for pediatric emergency: implication on overcrowding at the emergency units. Saúde Debate [Internet]. 2013[cited 2018 May 13];37(96):51-61. Available from: http://www.scielo.br/pdf/sdeb/v37n96/07.pdf

15. Andrade CSM, Maracajá PB, Melo WF, Andrade EM, Oliveira TLL, Ribeiro SRS, et al. Nurses' performance in emergency services and emergency pediatric. INTESA [Internet]. 2016[cited 2018 May 13];10(1):18-27. Available from: www.gvaa.com.br/revista/index.php/INTESA/ article/download/4536/3895

16. Filócomo FRF, Harada MJCS, Mantovani R, Ohara CVS. Profile of accidents in children and adolescents receiving care at a public hospital. Acta Paul Enferm [Internet]. 2017[cited 2018 May 13];30(3):287-94. Available from: http://www.scielo.br/pdf/ape/v30n3/en_1982-0194ape-30-03-0287.pdf

17. Pite H, Wedi B, Borrego LM, Kapp A, Raap U. Management of childhood urticaria: current knowledge and practical recommendations. Acta Derm Venereol [Internet]. 2013[cited 2018 May 13];93(5):500-8. Available from: https://www.medicaljournals.se/acta/content/ abstract/10.2340/00015555-1573

18. Burokiené S, Raistenskis J, Burokaité $\mathrm{E}$, Cerkauskiené R, Usonis V. Factors determining parents' decisions to bring their children to the pediatric emergency department for a minor illness. Med Sci Monit [Internet]. 2017[cited 2018 May 13];23(607):4141-8. Available from: https://www.ncbi.nlm.nih.gov/pmc/articles/PMC5584823/

19. Morrison AK, Myrvik MP, Brousseau DC, Hoffmann RG, Stanley RM. The relationship between parent health literacy and pediatric emergency department utilization: a systematic review. Acad Pediatr [Internet]. 2013[cited 2018 May 13];13(5):421-9. Available from: https://linkinghub. elsevier.com/retrieve/pii/S1876-2859(13)00056-9

20. Santos CKR, Moraes JRMM, Santos NLP, Souza TV, Morais RCM, Azevedo SD. Quality of nursing care in a pediatric emergency department: the companions' view. Rev Enferm UERJ [Internet]. 2016[cited 2018 May 13];24(4):e17560. Available from: http://www.facenf.uerj.br/v24n4/ v24n4a03.pdf

21. Grafstein E, Wilson D, Stenstrom R, Jones C, Tolson M, Poureslami I, et al. A regional survey to determine factors influencing patient choices in selecting a particular emergency department for care. Acad Emerg Med [Internet]. 2013 [cited 2018 May 18];20(1):63-70. Available from: https://onlinelibrary.wiley.com/doi/abs/10.1111/acem.12063. 